\title{
उMR
}

\section{Protein extraction method for the proteomic study of Zymomonas mobilis during production of ethanol and levans}

\author{
D.R. Cavalcanti, C.B. Malafaia, T.D. Silva, B.S. Santos, \\ G.M.T. Calazans and M.V. Silva \\ Laboratório de Biologia Molecular, Departamento de Bioquímica, \\ Centro de Ciências Biológicas, Universidade Federal de Pernambuco, \\ Recife, PE, Brasil \\ Corresponding author: D.R. Cavalcanti \\ E-mail: danillocavalcanti@hotmail.com
}

Genet. Mol. Res. 14 (4): 14406-14421 (2015)

Received September 4, 2014

Accepted April 8, 2015

Published November 18, 2015

DOI http://dx.doi.org/10.4238/2015.November.18.4

\begin{abstract}
Zymomonas mobilis has aroused considerable interest owing to its rapid metabolism and efficiency in producing ethanol and by-products such as levans, sorbitol, and gluconic acid from simple sugars. We performed a proteomic analysis of Z. mobilis UFPEDA241 to provide a global profile of regulatory proteins. The choice of the methods of extraction and cell lysis are fundamental steps and of great importance for the detection and identification of intra- and extracellular proteins of a proteome. Strains were subjected to protein extraction methods using three different reagents: TRIzol, lysis buffer, and phenol. The optimum method was taken to be the one that produced the greatest quantity and quality of proteins in one dimension for further analysis in two dimensions during the production of ethanol and levans over 72 h. The results showed that the greatest amount of protein was obtained by the phenol method $(1.44 \pm 0.07 \mathrm{mg} / \mathrm{mL})$, which was significantly different $(\mathrm{P}<0.05)$ to the TRIzol $(1.11 \pm 0.01 \mathrm{mg} / \mathrm{mL})$, and lysis buffer
\end{abstract}


$(0.93 \pm 0.01 \mathrm{mg} / \mathrm{mL})$ methods (both with $\mathrm{P}>0.05)$. Fermentation at $20^{\circ} \mathrm{C}$ produced the highest level of levans, and using two-dimensional electrophoresis and mass spectrometry it was possible to identify 34 differentially expressed spots.

Key words: Fermentation; Protein; Proteomics; Zymomonas mobilis

\section{INTRODUCTION}

The use of biotechnological processes for the production of a wide variety of compounds has aroused growing interest, especially in recent decades. Many advances have been made and new tools have been employed in this area. Such interest may be justified by better biosynthesis techniques, which reduce energy consumption and increase the safety of the process. Highly specific enzymes that minimize the formation of by-products and have a low environmental impact are now being used (Yang et al., 2009).

In this context, Zymomonas mobilis has aroused considerable interest owing to its rapid metabolism and efficiency in producing ethanol and by-products, such as levans, sorbitol, and gluconic acid, from simple sugars. In addition, it presents other advantages such as lower biomass production, no need for controlled oxygen addition, and high suitability for genetic manipulations (Calazans, 1987; Najafpour, 2007; Ranzan, 2010). Z. mobilis is a Gram-negative, aero-tolerant, anaerobic bacterium that appears as short, thick rods measuring approximately $2.0-6.0 \mu \mathrm{m}$ long and 1.0-1.4 $\mu \mathrm{m}$ wide. They may appear alone or in pairs, are generally mobile, and possess one to four polar flagella. Concerning nutrition, they are not very demanding chemoorganotrophic organisms. With regards to cultivation conditions, they can tolerate low $\mathrm{pH}$ values of around 4.0 in most cases (Swings and De Ley, 1977; Yang et al., 2009). As a result of the use of this route, the energy efficiency of Z. mobilis is half that of Saccharomyces cerevisiae, which uses the Embden-MeyerhofParnas pathway (McGill and Dawes, 1971; Swings and De Ley, 1977; de Morais, 1993). These metabolic pathways are simpler than those used by other microorganisms. Z. mobilis catabolizes substrates with high specific contents of carbon, since a larger portion of the substrate is incorporated in the catabolism of the final product (Toma et al., 2003). Owing to these characteristics, genetic studies on this bacterium have been included in research programs. Studies have involved the improvement of mutant strains (Zaldivar et al., 2001) as well as the application of metabolic flow analysis, directed mutagenesis, insertion and/or deletion of specific genes, and metabolic engineering for the development of strains (Hatzimanikatis et al., 1998; Cornish-Bowden and Cárdenas, 2000). A physical map of the genome of $Z$. mobilis and its transcriptional ribosomal unit (Kang and Kang, 1998; Lee et al., 2001) has contributed to the discovery of the first complete genome of this microorganism (Seo et al., 2005). Thus, the development of studies on strains of this species at the transcriptomic, metabolomic (Yang et al., 2009), and proteomic levels continues.

Industrial interest in microbial polysaccharides lies in the fact that they have simple properties, guarantee a supply of material of constant quality and stable price, and their production is not subject to weather variations. Microbial polysaccharides are useful for the synthesis of pharmacologically active polymers used in the development of drug release materials (Calazans et al., 1997, 2000). In the food industry, these polysaccharides have many functional properties, acting as cryoprotectants, stabilizers, gelling agents, and thickeners, and are often the principal agents responsible for the texture (body, viscosity, and consistency) of processed foods. Levans are considered a good source of fructose; these polymers have been employed 
in the fixing of colors and flavors, as thickeners and stabilizers in gels for desserts, ice cream, and milk derivatives, in seasonings for salads, in drinks, toppings for confectionery products, and even as an embedded casing (Ernandes and Garcia-Cruz, 2005).

The characterization of microorganisms using proteomic methods, as well as other biological system approaches, such as genomics, transcriptomics, and metabolomics, will improve our understanding of their biology (Mehmeti et al., 2011). The identification of genes has contributed to the understanding of the mechanism of modulation of microorganisms under different abiotic conditions (Amaral et al., 2008). However, transcriptional changes do not reflect the expression of proteins (Gygi et al., 1999) since post-transcriptional processes, which change the amount of active protein derived from synthesis, modification, and degradation of the protein, are not taken into consideration. These processes can produce a dramatic increase in the proteome without a concomitant increase in gene expression. Thus, complementary approaches such as proteomic studies may help identify the proteins involved in the response of microorganisms to environmental conditions (Chen and Harmon, 2006).

While the genome of an organism remains relatively stable throughout its life, the proteome is extremely dynamic and variable. Proteomic analysis determines if a gene is being expressed, that is, the relative concentration of the product, and ultimately the changes that may occur in the proteins after translation. It can also show how these metabolic, regulatory, and signaling processes become dysfunctional in disease states, and how they can be manipulated through, for example, the administration of drugs or gene therapy. Protein extraction is a challenging and inconsistent process that has been a problem for scientists (Galdos, 2009).

There are several protocols reported in the literature for the extraction of proteins. These are related to the purpose of the extraction, that is, measurement of concentration or enzymatic activity, separation by chromatographic or electrophoretic techniques, establishment of the sequence of amino acids, or determination of the three-dimensional structure of a protein. However, the extraction steps should be simple to ensure reproducibility of the results and minimize structural changes in the proteins, and to avoid chemical modifications during determination. Cell disruption, removal of interfering substances, and solubilization are the three basic steps in the preparation of protein samples (Rabilloud et al., 2010).

An efficient methodology for protein extraction is important for sample preparation, two-dimensional polyacrylamide gel electrophoresis (2-D-PAGE), and subsequent mass spectrometry (MS). Yet there are few studies offering comparison of these methods of protein extraction (Natarajan et al., 2005). These techniques can vary widely in reproducibility and in the representation of the total proteome. Despite this, many methods have been developed and reported. However, these have to be adapted, and sometimes combined, to obtain the best possible yield and purity for different species of organisms, for the type of sample to be analyzed, and for the proteins of interest. Therefore, the method of protein extraction for the accurate analysis of proteins remains a challenge for scientists (Natarajan et al., 2005). Thus, the objective of this study was to identify differentially expressed proteins in the production of levans and ethanol by Z. mobilis using sodium dodecyl sulfate (SDS)-PAGE for further 2-D analysis.

\section{MATERIAL AND METHODS}

\section{Microorganism and culture media}

The strain of Z. mobilis used was ZAG-12 (UFPEDA241), a result of the merger of the 
spheroplast strains Ag11 (UFPEDA198) and ZAP (UFPEDA205), belonging to the Culture Collection of the Department of Antibiotics at the Federal University of Pernambuco. Microorganisms were grown in SSDL liquid medium, comprising $20.0 \mathrm{~g} / \mathrm{L}$ glucose and $5.0 \mathrm{~g} / \mathrm{L}$ yeast extract, at pH 6.5 in a microbiological greenhouse at $30^{\circ} \mathrm{C}$ for $24 \mathrm{~h}$ (Swings and De Ley, 1977). After growth, the cultures were transferred to Erlenmeyer flasks containing an inoculum preparation medium comprising $100.0 \mathrm{~g} / \mathrm{L}$ sucrose; $5.0 \mathrm{~g} / \mathrm{L}$ yeast extract; $2.0 \mathrm{~g} / \mathrm{L} \mathrm{KH}_{2} \mathrm{PO}_{4} ; 0.5 \mathrm{~g} / \mathrm{L} \mathrm{MgSO}_{4} \cdot 7$ $\mathrm{H}_{2} \mathrm{O}$; and $1.0 \mathrm{~g} / \mathrm{L}\left(\mathrm{NH}_{4}\right)_{2} \mathrm{SO}_{4}$. The $\mathrm{pH}$ of this medium was adjusted to 6.0. The bottles were then placed in an oven at $30^{\circ} \mathrm{C}$ for $24 \mathrm{~h}$. The medium used in the production of levans was prepared with the same composition, doubling the concentration of each component, with the $\mathrm{pH}$ adjusted to 6.0. The experiment was conducted in triplicate (Calazans, 1987).

\section{Fermentation processes}

\section{Effect of temperature on the production of levans}

The experiments were conducted with the lineage Z. mobilis ZAG-12 in $500 \mathrm{~mL}$ Pyrex bottles containing $300 \mathrm{~mL}$ fermentation medium. For the inoculum, a $10 \%$ volume of the culture was used, grown at $30^{\circ} \pm 1^{\circ} \mathrm{C}$ for $24 \mathrm{~h}$ of pre-fermentation. The fermentations were carried out at temperatures of $20^{\circ}, 30^{\circ}$, and $40^{\circ} \pm 1^{\circ} \mathrm{C}$ for $72 \mathrm{~h}$, without agitation. Fermentation bottles subjected to a temperature of $20^{\circ} \mathrm{C}$ were placed in a refrigerated incubator. Samples for measurements of biomass, sucrose, $\mathrm{pH}$, and levans produced were harvested at $0,24,48$, and $72 \mathrm{~h}$. The fermented mash was sown on agar medium to investigate the presence of possible contaminants in the fermentation at the times previously mentioned (Silva, 1996). There was no growth of $Z$. mobilis on this medium owing to the absence of certain essential factors for this bacterium. The appearance of colonies implies the presence of contaminants.

\section{Quantitative determinations to accompany the fermentation processes}

\section{Levans dosage}

The levans from the fermented liquid were precipitated with absolute ethanol, by adjusting the water-alcohol mixture to $70 \%(\mathrm{v} / \mathrm{v})$ in ethanol. An addition of $15 \mathrm{~mL}$ ethanol at $-20^{\circ} \mathrm{C}$ was made to $5 \mathrm{~mL}$ fermented liquid, which had previously been filtered through a porous $0.22-\mu \mathrm{m}$ membrane by a vacuum filtration system (Millipore). After adding $15 \mathrm{~mL}$ absolute ethanol to $5 \mathrm{~mL}$ filtrate, the samples were centrifuged at $4200 \mathrm{~g}$ for $10 \mathrm{~min}$. The supernatant was discarded and $5 \mathrm{~mL}$ distilled water was added to remove levans from the sides of the Falcon tube. This process was carried out twice. The concentrations of precipitated levans were measured in $\mathrm{g} / \mathrm{L}$ by dry weight in previously dried and tared weighing filters, which were placed in an oven at $110^{\circ} \mathrm{C}$ for $24 \mathrm{~h}$ (Reiss and Hartmeier, 1990).

\section{Determination of carbohydrates and ethanol by high-performance liquid chromatography}

The quantification of sucrose, glucose, fructose, and ethanol produced by the Z. mobilis ZAG-12 was achieved using high-performance liquid chromatography with refractive index detection (Agilent, 1100 Series - Agilent Technologies, Waldbronn, Germany). For this 
analysis, an Aminex HPX-87H column was used, with $5 \mu \mathrm{M}$ sulfuric acid as the mobile phase, at a flow rate of $0.6 \mathrm{~mL} / \mathrm{min}$ and a temperature of $60^{\circ} \mathrm{C}$. The mobile phase was prepared with ultrapure water and subsequently filtered through a $0.22-\mu \mathrm{m}$ micropore filter. The quantification used the external standard method, with a calibration curve made simultaneously with the analysis of data obtained during fermentation to prevent errors in the analysis. Since this method is sensitive to errors in the preparation of the samples and standards, as well as the injection of the sample and standard solutions, this procedure was necessary for each analysis (Ribani et al., 2004). The samples and standards were diluted in the mobile phase, filtered, and injected automatically in a $5-\mu \mathrm{L}$ volume.

\section{Protein extraction methods}

\section{TRIzol}

TRIzol reagent was used $\left(\right.$ Invitrogen $\left.^{\circledR}\right)$ following the manufacturer protocol.

\section{Lysis buffer}

Lysis buffer $(1.0 \mathrm{~mL})$ comprising: $420.0 \mathrm{~g} / \mathrm{L} 7 \mathrm{M}$ urea; $152.0 \mathrm{~g} / \mathrm{L} 2 \mathrm{M}$ thiourea; 40.0 $\mathrm{g} / \mathrm{L} 4 \%$ 3-[(3-cholamidopropyl)dimethylammonio]-1-propanesulfonate; and $10.0 \mathrm{~g} / \mathrm{L} 1 \%$ dithiothreitol (DDT) was added to the samples kept on ice. They were then centrifuged at $14,000 \mathrm{~g}$ and $4^{\circ} \mathrm{C}$ for $30 \mathrm{~min}$, and the supernatant was transferred to another microtube and stored at $-20^{\circ} \mathrm{C}$ (Lee and Lo, 2008).

\section{Phenol}

The cells were collected by centrifugation and the pellets were washed in phosphatebuffered solution comprising $1.24 \mathrm{~g} / \mathrm{L} \mathrm{K}_{2} \mathrm{HPO}_{4} ; 0.39 \mathrm{~g} / \mathrm{L} \mathrm{KH}_{2} \mathrm{PO}_{4}$; and $8.8 \mathrm{~g} / \mathrm{L} \mathrm{NaCl}$, with the $\mathrm{pH}$ adjusted to 7.2. The pellets were suspended in $0.75 \mathrm{~mL}$ extraction buffer comprising 0.7 M sucrose; $0.5 \mathrm{M}$ Tris- $\mathrm{HCl} ; 30 \mathrm{mM} \mathrm{HCl} ; 50 \mathrm{mM}$ ethylenediaminetetraacetic acid; $0.1 \mathrm{M} \mathrm{KCl}$; and $40 \mathrm{mM}$ DDT, with the $\mathrm{pH}$ adjusted to 7.0, and incubated for $15 \mathrm{~min}$ at room temperature. The same volume of phenol was added to the pellets and after 15 min of agitation, the suspension was centrifuged at $10,000 \mathrm{~g}$ and $4^{\circ} \mathrm{C}$ for $3 \mathrm{~min}$. The supernatant was discarded. This step was repeated twice. Proteins were precipitated with five volumes of $0.1 \mathrm{M}$ ammonium acetate in methanol and centrifuged at $14,000 \mathrm{~g}$ and $4^{\circ} \mathrm{C}$ for $30 \mathrm{~min}$. The precipitate was washed once with $1.0 \mathrm{~mL} 80 \%$ acetone and centrifuged at $8000 \mathrm{~g}$ and $4^{\circ} \mathrm{C}$ for $5 \mathrm{~min}$. The supernatant of the samples was discarded and the pellet was dried at room temperature for $5 \mathrm{~min}$. Then, 100 $\mu \mathrm{L} 1 \%$ sodium dodecyl sulfate and phosphate-buffered saline was added to dissolve the proteins. The pellet was broken and placed in a water bath at $50^{\circ} \mathrm{C}$ for $15 \mathrm{~min}$. Subsequently, the samples were stored at $-20^{\circ} \mathrm{C}$ (Mehta and Rosato, 2001).

\section{Total protein quantification}

Proteins were quantified according to the methodology of Lowry et al. (1951). A Pierce ${ }^{\circledR}$ BCA Protein Assay Thermo Scientific kit was used, following the manufacturer protocol. 


\section{D electrophoresis and analysis of images}

The equivalent of $200 \mu \mathrm{g}$ protein was precipitated with trichloroacetic acid and redissolved in rehydration buffer. Focusing was done using an immobilized $\mathrm{pH}$ gradient. Immobilized $\mathrm{pH}$ gradient strips were rehydrated in an IPGphor 3 isoelectric focusing apparatus (GE Healthcare, Piscataway, NJ, USA) for $16-20 \mathrm{~h}$ at $20^{\circ} \mathrm{C}$. The isoelectric focusing was performed in the following steps: 500, 800, 2900, and 11,300 Vh. After focusing, the strips were washed with ultrapure water, stored at $-80^{\circ} \mathrm{C}$, and balanced in two disulfide bridge-reducing solutions (Görg et al., 2004). The second dimension of the electrophoresis was performed in six vertical homogeneous $15 \%$ acrylamide gels, three for the samples of $0 \mathrm{~h}$ and three for the samples of $72 \mathrm{~h}$, as described by Laemmli (1970). The first step consisted of $50 \mathrm{mg}$ DDT for each $5 \mathrm{~mL}$ equilibrium solution (composition: $6 \mathrm{M}$ urea; $75 \mathrm{mM}$ Tris- $\mathrm{HCl}, \mathrm{pH} 8.8 ; 29.3 \%$ glycerol; $2 \%$ sodium dodecyl sulfate; and $0.002 \%$ bromophenol blue of a $1 \%$ solution). The separation of proteins was made at $10^{\circ} \mathrm{C}$ in a Hoefer SE600 Ruby cube (Amersham Bioscience). The images of the gels were acquired with a resolution of $300 \mathrm{dpi}$, then analyzed with the ImageMaster 2-D Platinum 6.0 software (GE Healthcare), in accordance with the manufacturer protocols. The quantity of each spot was normalized by the total intensity of valid spots.

\section{Analysis of proteins by matrix-assisted laser desorption/ionization time-of-flight/ time-of-flight MS (MALDI-TOF/TOF MS)}

The digestion of proteins on the gels was performed as described by Shevchenko et al. (2006), with some changes. Peptides were dissolved in $10 \mu \mathrm{L} 0.1 \%$ trifluoroacetic acid. The saturated solution of $4 \mathrm{mg} / \mathrm{mL}$ alpha-cyano-4-hydroxycinnamic in $50 \%$ acetonitrile and $0.3 \%$ trifluoroacetic acid was mixed with an equal amount of sample and placed in an AnchorChip 800/384 plate (Bruker Daltonik $\mathrm{GmbH}$ ) and dried in a laminar airflow for recrystallization. The samples were analyzed in a MALDI TOF/TOF MS (Ultraflex, Bruker Daltonik GmbH) in reflectron mode. Peptides with a signal-to-noise ratio above 100 had their MS/MS analyzed using the LIFT technology that is embedded in the Ultraflex MS; on average, five MS/MS spectra were measured for each protein digested using two to five identified peptides. The data processing was carried out using flexAnalysis and BioTools software packages (Bruker Daltonik $\mathrm{GmbH}$ ).

\section{MS/MS data analysis}

Data analysis was performed using the BioTools 3.0 software and the MASCOT search tool (Matrix Science, MK). The searches were conducted using the following parameters: mass tolerance was set to $0.7 \mathrm{Da}$ for ion fragments; trypsin was defined as a proteolytic enzyme with two missing cleavages; peptide loading of +1 was used; the carbamidomethylation of cysteine residues was defined as fixed modification; and the oxidation of methionine residues was defined as variable modification.

\section{RESULTS}

\section{Protein extraction methods}

The concentrations of proteins extracted using the three methods are shown in Table 1. 
The results showed that the greatest amount of protein was obtained by the phenol method, which proved to be significantly different $(\mathrm{P}<0.05)$ from the TRIzol and lysis buffer methods (both with $\mathrm{P}>0.05$ ).

Table 1. Protein concentration $(\mathrm{mg} / \mathrm{mL})$ obtained by three different methods of protein extraction.

\begin{tabular}{lccc}
\hline Microorganism & TRIzol & Lysis buffer & Phenol \\
\hline Zymomonas mobilis ZAG-12 & $1.11 \pm 0.01$ & $0.93 \pm 0.01$ & $1.44 \pm 0.07$ \\
\hline
\end{tabular}

Values are reported as means $\pm \mathrm{SD}$ for results of three experiments.

The samples were later subjected to 2-D electrophoresis and staining with Coomassie Brilliant Blue, whereupon it was noticed that the three methods detected an ample amount of acidic proteins at $\mathrm{pH}$ values ranging from around 3 to 6.5. However, the TRIzol method proved to be efficient in detecting a greater number of proteins in a $\mathrm{pH}$ range between neutral and alkaline, compared with the lysis buffer and phenol methods (Figure 1).
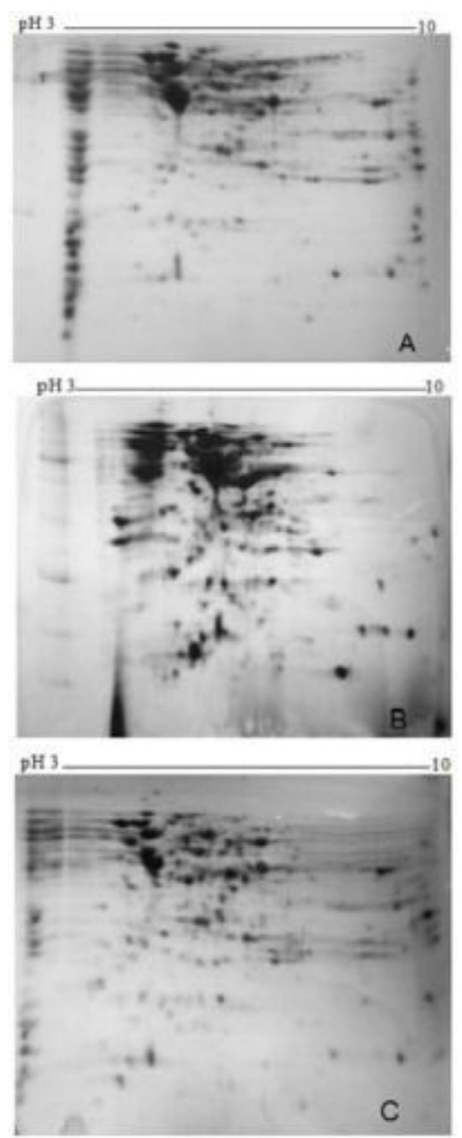

Figure 1. Representation of the protein profiles on 2-D gels of Zymomonas mobilis ZAG-12 using (A) TRIzol, (B) lysis buffer, and (C) phenol. 


\section{Levans and ethanol production by Z. mobilis ZAG-12}

The largest production of levans $(3.90 \mathrm{~g} / \mathrm{L})$ was observed at $20^{\circ} \mathrm{C}$, followed by 1.79 $\mathrm{g} / \mathrm{L}$ at $30^{\circ} \mathrm{C}$ and $0.31 \mathrm{~g} / \mathrm{L}$ at $40^{\circ} \mathrm{C}$ (Figure 2). With respect to ethanol production over $72 \mathrm{~h}$ of fermentation, the highest production (approximately $9.36 \mathrm{~g} / \mathrm{L}$ ) occurred at $30^{\circ} \mathrm{C}$, followed by $6.86 \mathrm{~g} / \mathrm{L}$ at $20^{\circ} \mathrm{C}$ and $3.36 \mathrm{~g} / \mathrm{L}$ at $40^{\circ} \mathrm{C}$ (Figures 3 , 4, and 5). The highest consumption of substrate occurred at $30^{\circ} \mathrm{C}$ (approximately $157.13 \mathrm{~g} / \mathrm{L}$ sucrose consumed) (Figure 4), followed by $143.22 \mathrm{~g} / \mathrm{L}$ at $40^{\circ} \mathrm{C}$ (Figure 5) and $142.88 \mathrm{~g} / \mathrm{L}$ at $20^{\circ} \mathrm{C}$ (Figure 3). At temperatures of 20 and $40^{\circ} \mathrm{C}$, a higher concentration of residual substrate was registered, corresponding to $11 \%$ of the initial substrate, whereas at $30^{\circ} \mathrm{C}$, the residual substrate corresponded to $7 \%$ of the initial substrate. Figures 3, 4, and 5 show that after $72 \mathrm{~h}$ of fermentation, the substrate was not fully consumed. The continuation of the process for a longer period could result in higher yields of levans and consequently a reduction of the residual substrate.

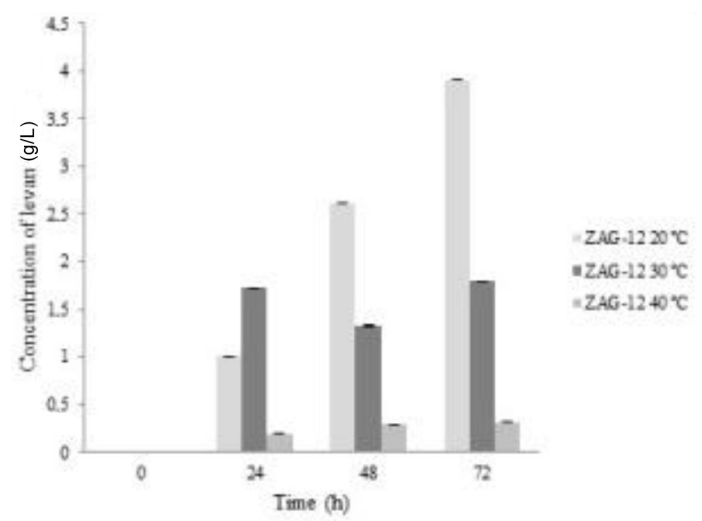

Figure 2. Production of levan by Zymomonas mobilis ZAG-12 in $72 \mathrm{~h}$ of fermentation.

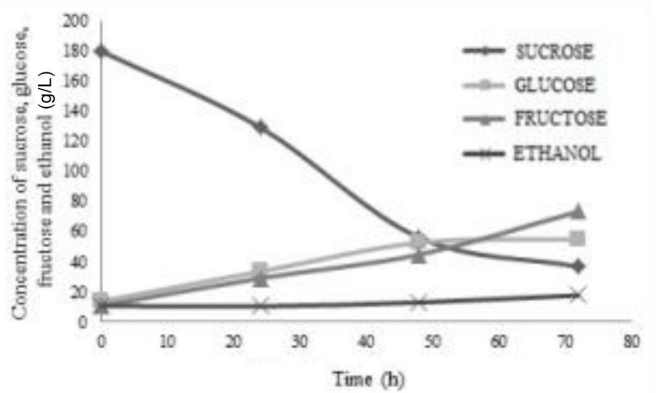

Figure 3. Consumption of sucrose and concentration of glucose, fructose and ethanol in $72 \mathrm{~h}$ of fermentation by Zymomonas mobilis ZAG-12, at $20^{\circ} \mathrm{C}$.

Although the greatest consumption of substrate occurred at $30^{\circ} \mathrm{C}$ (Figure 4), the highest conversion rate of product into substrate $(\mathrm{YP} / \mathrm{S})$ occurred at $20^{\circ} \mathrm{C}$. At this temperature, the conversion factor of sucrose into levans was about twice that of the $\mathrm{YP} / \mathrm{S}$ at $30^{\circ} \mathrm{C}$ and thirteen times greater than the $\mathrm{YP} / \mathrm{S}$ at $40^{\circ} \mathrm{C}$ (Table 2). At the same temperature, it can also be noted that the YP/S for ethanol was greater (Table 3). 


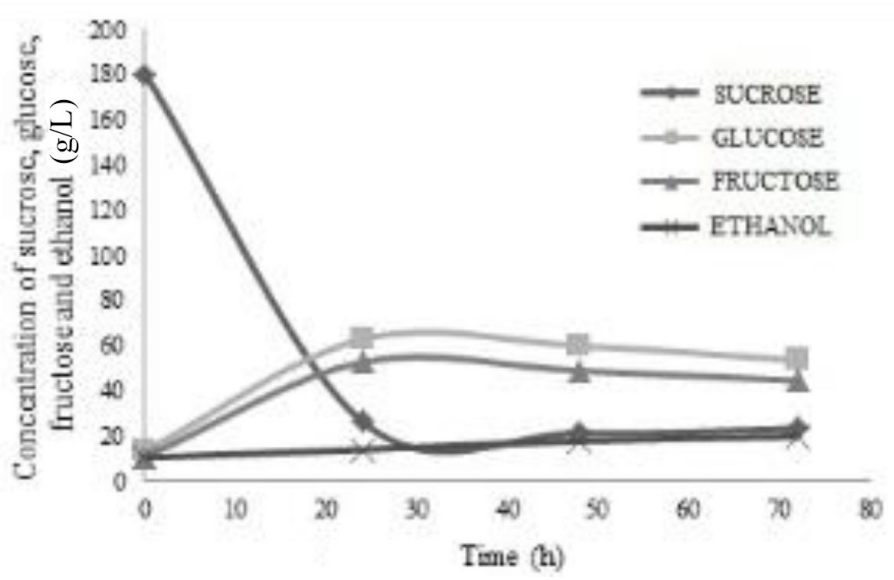

Figure 4. Consumption of sucrose and concentration of glucose, fructose and ethanol in $72 \mathrm{~h}$ of fermentation by Zymomonas mobilis ZAG-12, at $30^{\circ} \mathrm{C}$.

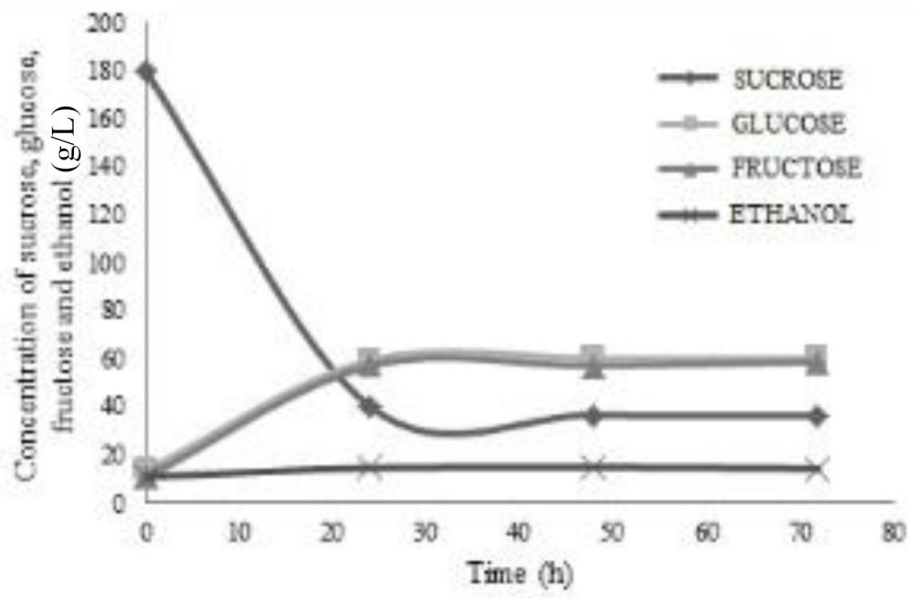

Figure 5. Consumption of sucrose and concentration of glucose, fructose and ethanol in $72 \mathrm{~h}$ of fermentation by Zymomonas mobilis ZAG-12, at $40^{\circ} \mathrm{C}$.

Table 2. Yield of levan by Zymomonas mobilis ZAG-12, in $72 \mathrm{~h}$ of fermentation.

\begin{tabular}{lc}
\hline Temperature $\left({ }^{\circ} \mathrm{C}\right)$ & YP/S $(\mathrm{g} / \mathrm{g})$ \\
\hline $20^{\circ}$ & 0.027 \\
$30^{\circ}$ & 0.011 \\
$40^{\circ}$ & 0.002 \\
\hline
\end{tabular}

Table 3. Yield of ethanol by Zymomonas mobilis ZAG-12, in $72 \mathrm{~h}$ of fermentation.

\begin{tabular}{lc}
\hline Temperature $\left({ }^{\circ} \mathrm{C}\right)$ & YP/S $(\mathrm{g} / \mathrm{g})$ \\
\hline $20^{\circ}$ & 0.065 \\
$30^{\circ}$ & 0.043 \\
$40^{\circ}$ & 0.023 \\
\hline
\end{tabular}

Genetics and Molecular Research 14 (4): 14406-14421 (2015) 


\section{Protein analysis}

Approximately $1.1 \mathrm{mg} / \mathrm{mL}$ protein was obtained from $6 \mathrm{~mL}$ fermented substrate. The resolution of approximately $200 \mu \mathrm{g}$ proteins loaded on each gel showed an average of 500 spots with an isoelectric point (pI) of 4-7 and a molecular mass of 10-220 kDa (Figures 6 and 7). The magnified image of 2-D gels can be seen in Figure 8. 2-D comparative analysis was conducted between the treatments $(0$ and $72 \mathrm{~h})$, where the proteins found at time $0 \mathrm{~h}$ refer to proteins from the inoculum found at $30^{\circ} \mathrm{C}$ at a concentration of $100 \mathrm{~g} / \mathrm{L}$. The differentially expressed proteins, which were identified by MALDI-TOF/TOF (MS/MS), had an identification rate of $77.27 \%$ (34 of 44 spots).

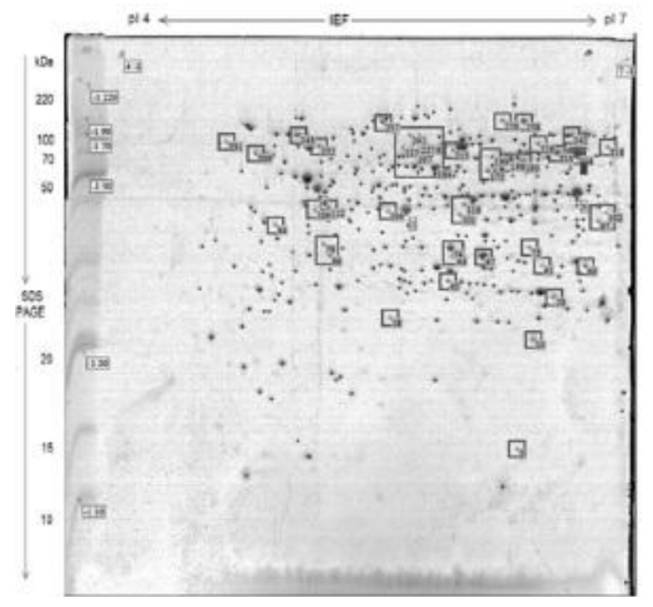

Figure 6. Overview of the proteome of Zymomonas mobilis ZAG-12 at $0 \mathrm{~h}$ of fermentation for the production of levan, separated by bidimensional electrophoresis. The 2-D resolution of the proteome with IEF/SDS-PAGE showed $\mathrm{pI}$ of 4-7 linear and molecular mass of 10-220 kDa.

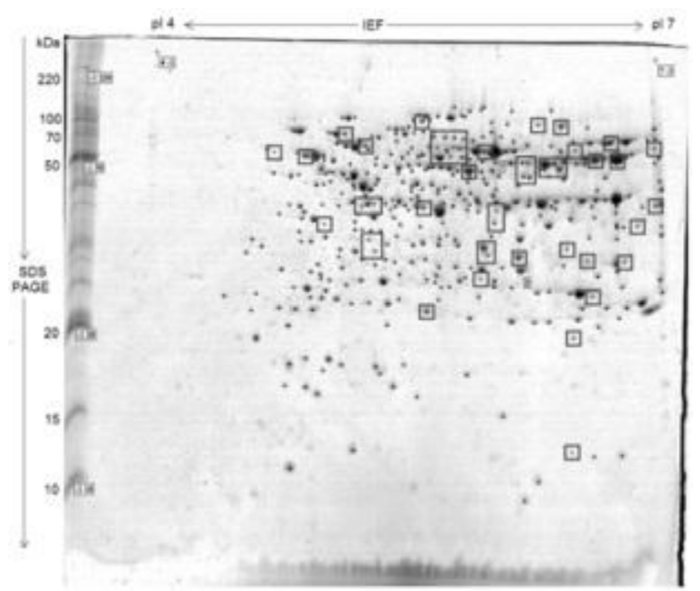

Figure 7. Overview of the proteome of Zymomonas mobilis ZAG-12 at $72 \mathrm{~h}$ of fermentation for the production of levan, separated by bidimensional electrophoresis. The 2-D resolution of the proteome with IEF/SDS-PAGE showed $\mathrm{pI}$ of 4-7 linear and molecular mass of 10-220 kDa. 


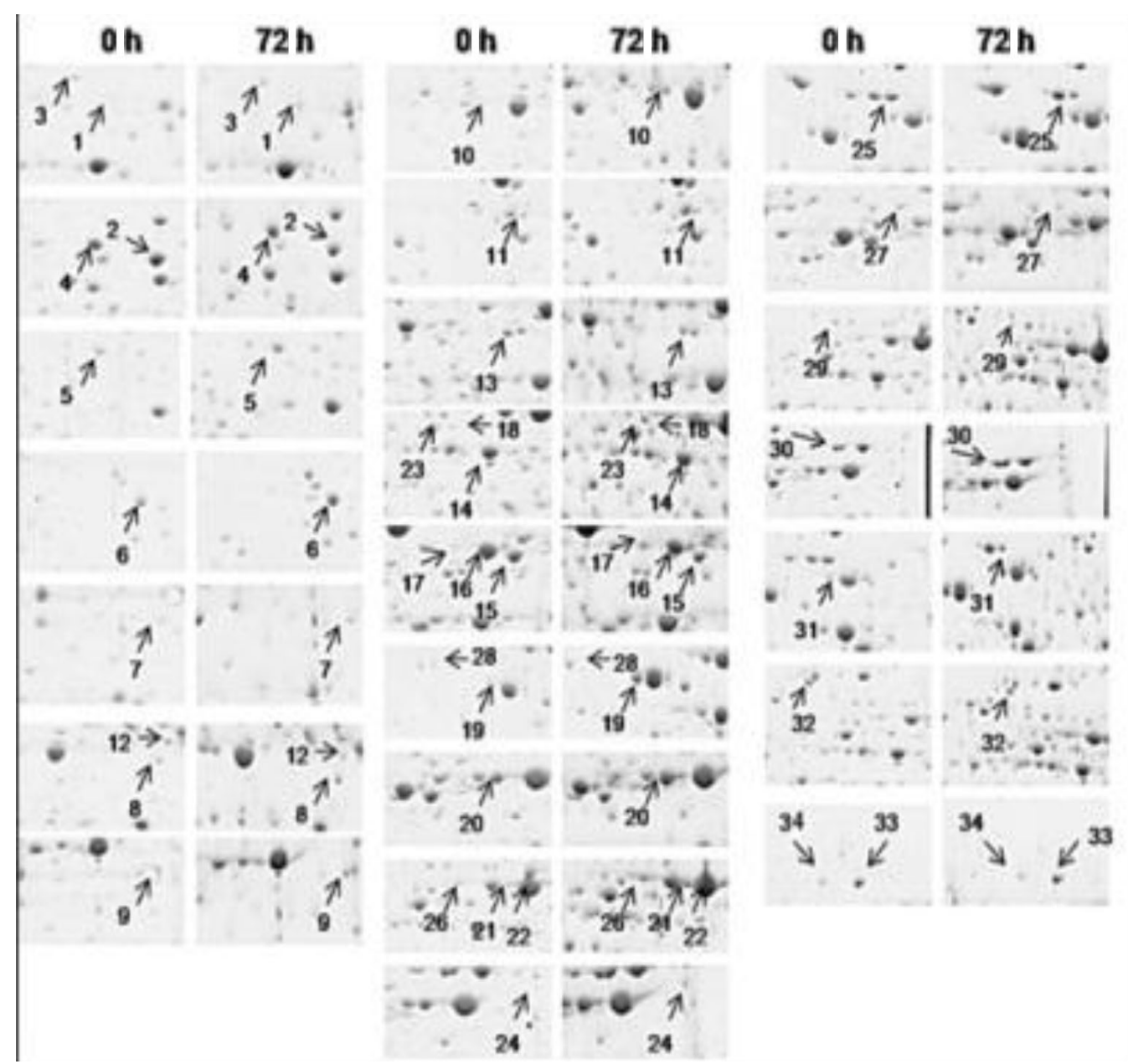

Figure 8. Close-up of the areas of the bidimensional gels showing spots of differentially expressed proteins at 0 and $72 \mathrm{~h}$. The indicated numbers are in accordance with those cited in Table 4.

\section{Protein regulation in the process of levans and ethanol production}

Protein reactions in the production of levans and ethanol were evaluated by comparing the gels in triplicate at both the initial and final time. Using the 2-D-PAGE approach, it was possible to identify 34 differentially expressed spots (Table 4). Among these, 19 showed increased expression at $0 \mathrm{~h}$ of fermentation (proteins from the inoculum) and 15 showed increased expression at $72 \mathrm{~h}$ of fermentation.

Most of the proteins identified are involved in the metabolism of carbohydrates (57\%); others in mechanisms of translation and transcription (Figure 9). These act as enzymes catalyzing important reactions in several metabolic pathways for the production of ethanol, levans, and other products (Figure 10). 


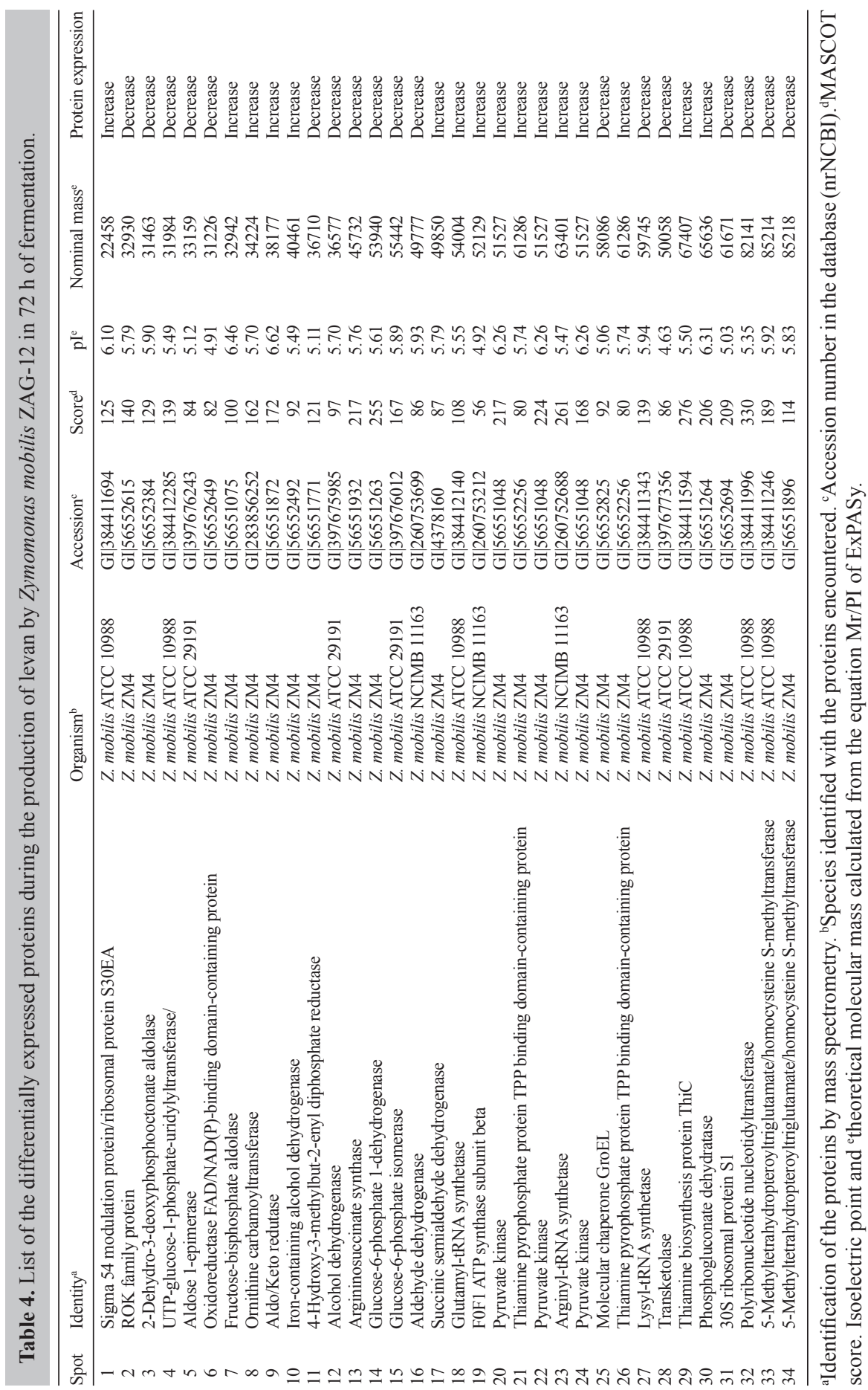




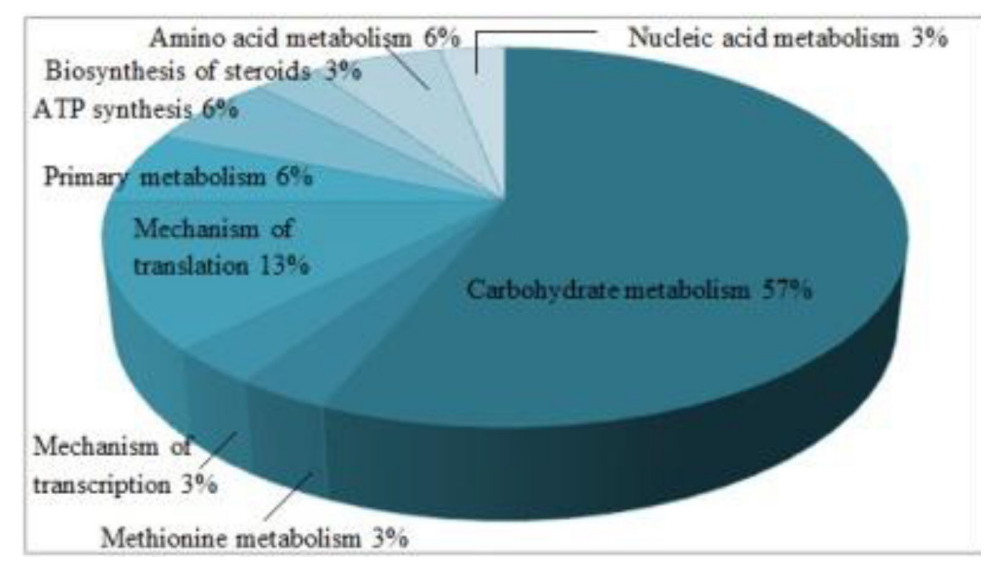

Figure 9. Proportional representation of the proteins identified according to their metabolic function in Zymomonas mobilis ZAG-12.

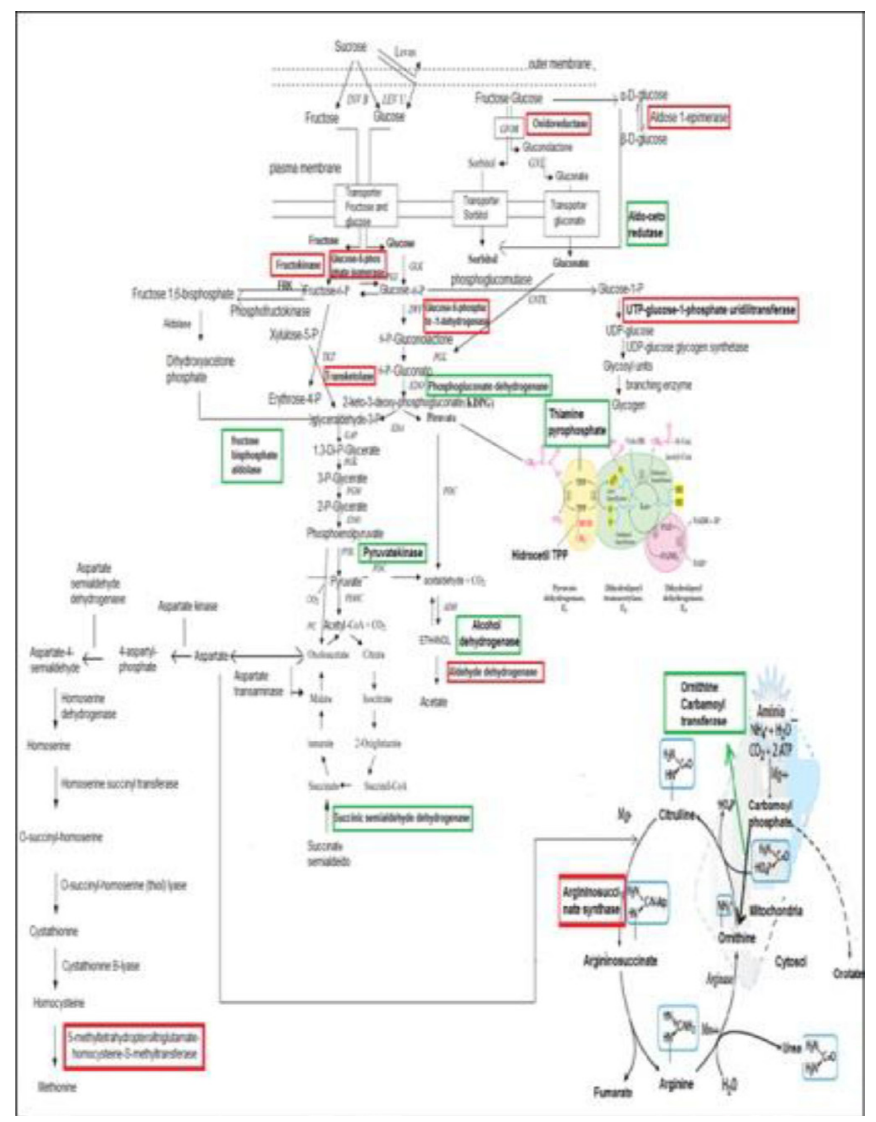

Figure 10. Metabolic pathways of Zymomonas mobilis. Highlighted in green, the differentially expressed proteins at $72 \mathrm{~h}$ of fermentation; highlighted in red, the differentially expressed proteins coming from the inoculum. (Sources: Sprenger, 1996, adapted; http://healthmetrix.wordpress.com/tag/amonia). 


\section{DISCUSSION}

Sample preparation and high-quality resolution are the most important factors in the analysis and quantification of high- and low-protein expression in 2-D electrophoresis. It is quite relevant to select a standard test for the appropriate choice of a sample, as proteins have different chemical and physical properties, based on the fact that certain extraction protocols can favor different types of sample proteins (Mehmeti et al., 2011). Obtaining good-quality results on 2-D electrophoresis gels depends on the way the sample is treated prior to $\mathrm{pI}$ focusing (Lee and Lo, 2008).

In proteomics, evaluation, selection, and standardization of efficient methods are required for the analysis of proteins, since the presence of non-protein impurities can severely affect the quality of 2-D-PAGE separation by the formation of stains or artifacts (Mehmeti et al., 2011). $Z$. mobilis bacteria contain a large quantity of substances that can affect the quality of electrophoretograms, such as salts and polysaccharides, among others, which if not properly treated will produce a poor-quality result. Amphoteric compounds in samples dramatically affect the $\mathrm{pI}$ gradient, resulting in narrow vertical areas without protein stains. For this reason, the reagents used must be of low salt content and high purity. Time is also a factor to be taken into consideration to reduce the possibility of protein loss and modification (Lee and Lo, 2008).

Of the three protein extraction procedures, TRIzol extraction resulted in a lower concentration of proteins than did phenol extraction. However, the TRIzol method presented good resolution of items stained with a light background (Figure 1A). The lysis buffer extraction method was the simplest and fastest of the three methods tested; however, the amount of proteins extracted was much lower than in the other methods. Lee and Lo (2008) compared the TRIzol method with the lysis buffer and acetone precipitation methods in dinoflagellates. Of these, the TRIzol method proved to be superior, in terms of both protein concentration and image resolution. Excessive streaking, spots, and agglomerations within a single region in the $\mathrm{pH}$ range of 3-10 make it difficult to determine the number of spots, as in the lysis buffer method (Figure 1B). In this case, it was necessary to use strips with a $\mathrm{pH}$ of 4-7, as the majority of the proteins are acidophilic.

Samples treated with TRIzol provided the best results among the methods examined, showing smaller steaks. In short, with regards to 2-D profiles in the studies, TRIzol is better for the extraction of proteins from chemically resistant samples with thick cell walls in the presence of interfering compounds, such as DNA, RNA, carbohydrates, and proteolytic and oxidative enzymes (Lee and Lo, 2008).

The greatest consumption of substrate occurred at $30^{\circ} \mathrm{C}$; the low rate of conversion of sucrose to levans can be explained by the fact that higher temperatures, around $30^{\circ}-35^{\circ} \mathrm{C}$, favor ethanol production, as well as the production of gluconic acid and sorbitol by-products, which contribute to the decrease in the conversion of the substrate to levans (Viikari and Gisler, 1986; Doelle et al., 1993; Calazans, 1997).

The results obtained for the $\mathrm{YP} / \mathrm{S}$ of levans were corroborated by those described in a similar study, confirming that at temperatures below $30^{\circ} \mathrm{C}$ there is greater polymerization of fructose into levans. Temperatures below $30^{\circ} \mathrm{C}$ favor polymerization of fructose into levans, at the expense of ethanol production, which simultaneously inhibits the activity of certain enzymes that are involved in substrate conversion to ethanol, gluconic acid, and sorbitol at temperatures up to $25^{\circ} \mathrm{C}$ (Calazans, 1997). The conversion factors for both levans and ethanol were greater at $20^{\circ} \mathrm{C}$. Based on the results obtained, $20^{\circ} \mathrm{C}$ was chosen as the optimum temperature for proteomic analysis, at which levans were favored in comparison with the other temperatures tested. 


\section{Conflicts of interest}

The authors declare no conflict of interest.

\section{ACKNOWLEDGMENTS}

The authors declare their gratitude for research grants supplied by the following Brazilian agencies: Conselho Nacional de Desenvolvimento Científico e Tecnológico (CNPq), Coordenação de Aperfeiçoamento de Pessoal de Nível Superior (CAPES), and Fundação de Amparo à Ciência e Tecnologia do Estado de Pernambuco (CAPES).

\section{REFERENCES}

Amaral DOJ, Lima MMA, Resende LV and Silva MV (2008). Differential gene expression in tomato induced by salicylic acid and Fusarium oxysporum f. sp. lycopersici. Pesq. Agropec. Bras. 43: 1017-1023.

Calazans GMT (1987). Fermentação etanólica por Zymomonas mobilis (cepa ZAP). Dissertation, Federal University of Pernambuco, Recife.

Calazans GMT (1997). Produção de levansa para uso clínico. Dissertation, Federal University of Rio de Janeiro, Rio de Janeiro.

Calazans GMT, Lopes CE, Lima RMOC and França FP (1997). Antitumour activities of levans produced by Zymomonas mobilis strains. Biotechnol. Lett. 19: 19-21.

Calazans GMT, Lima RC, de França FP and Lopes CE (2000). Molecular weight and antitumour activity of Zymomonas mobilis levans. Int. J. Biol. Macromol. 27: 245-247.

Chen S and Harmon AC (2006). Advances in plant proteomics. Proteomics 6: 5504-5516.

Cornish-Bowden A and Cárdenas ML (2000). From genome to cellular phenotype - a role for metabolic flux analysis? Nat. Biotechnol. 18: 267-268.

de Morais JO, Rios EM, Calazans GM and Lopes CE (1993). Zymomonas mobilis research in the Pernambuco Federal University. J. Biotechnol. 31: 75-91.

Doelle HW, Kirk L, Crittenden R, Toh H, et al. (1993). Zymomonas mobilis - science and industrial application. Crit. Rev. Biotechnol. 13: 57-98.

Ernandes FMPG and Garcia-Cruz CH (2005). Levansa bacteriana: aspectos tecnológicos, características e produção Semina: Cienc. Agrárias 26: 71-82.

Galdos ACR (2009). Análise proteômica do saco vitelino de bovinos. Dissertation, University of São Paulo, São Paulo.

Görg A, Weiss W and Dunn MJ (2004). Current two-dimensional electrophoresis technology for proteomics. Proteomics 4: 3665-3685.

Gygi SP, Rist B, Gerber SA, Turecek F, et al. (1999). Quantitative analysis of complex protein mixtures using isotopecoded affinity tags. Nat. Biotechnol. 17: 994-999.

Hatzimanikatis V, Emmerling M, Sauer U and Bailey JE (1998). Application of mathematical tools form metabolic design of microbial ethanol production. Biotechnol. Bioeng. 58: 154-161.

Kang HL and Kang HS (1998). A physical map of the genome of ethanol fermentative bacterium Zymomonas mobilis ZM4 and localization of genes on the map. Gene 206: 223-228.

Laemmli UK (1970). Cleavage of structural proteins during the assembly of the head of bacteriophage T4. Nature 227: 680-685.

Lee FW and Lo SC (2008). The use of Trizol reagent (phenol/guanidine isothiocyanate) for producing high quality twodimensional gel electrophoretograms (2-DE) of dinoflagellates. J. Microbiol. Methods 73: 26-32.

Lee JS, Jin SJ and Kang HS (2001). Molecular organization of the ribosomal RNA transcription unit and the phylogenetic study of Zymomonas mobilis ZM4. Mol. Cells 11: 68-74.

Lowry OH, Rosebrough NJ, Farr AL and Randall RJ (1951). Protein measurement with the Folin phenol reagent. J. Biol. Chem. 193: 265-275.

McGill DJ and Dawes EA (1971). Glucose and fructose metabolism in Zymomonas anaerobia. Biochem. J. 125: 1059-1068.

Mehmeti I, Kiran F and Osmanagaoglu O (2011). Comparison of three methods for determination of protein concentration in lactic acid bacteria for proteomics studies. Afr. J. Biotechnol. 10: 2178-2185.

Mehta A and RosatoYB (2001). Differentially expressed proteins in the interaction of Xanthomonas axonopodis pv. citri 
with leaf extract of the host plant. Proteomics 1: 1111-1118.

Najafpour GD (2007). Biochemical engineering and biotechnology. Elsevier, Amsterdam.

Natarajan S, Xu C, Caperna TJ and Garrett WM (2005). Comparison of protein solubilization methods suitable for proteomic analysis of soybean seed proteins. Anal. Biochem. 342: 214-220.

Rabilloud T, Chevallet M, Luche S and Lelong C (2010). Two-dimensional gel electrophoresis in proteomics: Past, present and future. J. Proteomics 73: 2064-2077.

Ranzan C (2010). Fermentação contínua de Z. mobilis: modelagem, ajuste de parâmetros e inferências a partir do consumo de hidróxido de sódio. Dissertation, Federal University of Rio Grande do Sul, Porto Alegre.

Redmond E (2010). Sobrecarga da amonia. Healthmetrix. Available at [ttps://healthmetrix.wordpress.com/2010/08/11/ sobrecarga-da-amonia/]. Accessed April 3, 2015.

Reiss M and Hartmeier W (1990). Levans Production with a flocculent strain of Zymomonas mobilis. Food Biotechnol. 4: 69-75.

Ribani M, Bottoli CBG, Collins CH, Jardim ICSF, et al. (2004). Validação em métodos cromatográficos e eletroforéticos. Quim. Nova 27: 771-780.

Seo JS, Chong H, Park HS, Yoon KO, et al. (2005). The genome sequence of the ethanologenic bacterium Zymomonas mobilis ZM4. Nat. Biotechnol. 23: 63-68.

Shevchenko A, Tomas H, Havlis J, Olsen JV, et al. (2006). In-gel digestion for mass spectrometric characterization of proteins and proteomes. Nat. Protoc. 1: 2856-2860.

Silva MCP (1996). Influência do controle do pH sobre a produção de levansa pela Zymomonas mobilis ZAG-12 em meio à base de sacarose. Dissertation, Federal University of Pernambuco, Recife.

Sprenger GA (1996). Carbohydrate metabolism in Zymomonas mobilis: a catabolic highway with some scenic routes. FEMS Microbiol. Lett. 145: 301-307.

Swings J and De Ley J (1977). The Biology of Zymomonas. Bacteriol. Rev. 41: 1-46.

Toma MM, Kalnenieks U, Berzins A, Vigants A, et al. (2003). The effect of mixing on glucose fermentation by Zymomonas mobilis continuous culture. Process Biochem. 38: 1347-1350.

Viikari L and Gisler R (1986). By-products in the fermentation of sucrose by different Zymomonas-strains. Appl. Microbiol. Biotechnol. 23: 240-244.

Yang S, Tschaplinski TJ, Engle NL, Carroll SL, et al. (2009). Transcriptomic and metabolomic profiling of Zymomonas mobilis during aerobic and anaerobic fermentations. BMC Genomics 10: 34.

Zaldivar J, Nielsen J and Olsson L (2001). Fuel ethanol production from lignocellulose: a challenge for metabolic engineering and process integration. Appl. Microbiol. Biotechnol. 56: 17-34. 